Article

\title{
The Effect of Rare Earths Additions on the Microstructure and the Corrosion Behavior of Sn-0.7Cu-0.075Al Solder Alloy
}

\author{
Wenchao Yang ${ }^{1,2}$, Zaixiang Du ${ }^{1,2}$, Shuyuan $\mathrm{Yu}^{3,4}$, Yitai Li ${ }^{1,2, *}$, Junli Feng ${ }^{3,4}$, Xuanchen Wei ${ }^{1,2}$, \\ Qiang $\mathrm{Li}^{1,2}$ and Yongzhong Zhan ${ }^{1,2, *}$ \\ 1 School of Resources, Environment and Materials, Guangxi University, Nanning 530004, China; \\ ywch053@163.com (W.Y.); imzx_to@126.com (Z.D.); xuanchen_wei@163.com (X.W.); \\ xutaofromyjt@163.com (Q.L.) \\ 2 Guangxi Key Laboratory of Processing for Non-ferrous Metal and Featured Materials, \\ Nanning 530004, China \\ 3 Shenzhen Customs Industrial Products Inspection Technology Center, Shenzhen 518067, China; \\ szciqysy@126.com (S.Y.); fjlhhp@foxmail.com (J.F.) \\ 4 Shenzhen Academy of Inspection and Quarantine, Shenzhen 518010, China \\ * Correspondence: lyt8590@126.com (Y.L.); zyzmatres@aliyun.com (Y.Z.); \\ Tel.: +86-771-3272311 (Y.Z.); Fax: +86-771-3233530 (Y.Z.)
}

Received: 23 October 2019; Accepted: 5 November 2019; Published: 12 November 2019

\begin{abstract}
Sn-0.7Cu-0.075Al solder alloy adding with Ce and La had been successfully prepared by applying ball-milling and vacuum arc remelting. The influence of $\mathrm{Ce}$ and $\mathrm{La}$ on microstructure and corrosion behavior of $\mathrm{Sn}-0.7 \mathrm{Cu}-0.075 \mathrm{Al}$ solder alloy was investigated. The results showed that $\mathrm{Ce}$ (La)-containing solders had refined grains and obvious directional tendency due to the dispersive refiner $\left(\mathrm{CeO}_{2}\right.$ and $\left.\mathrm{La}_{2} \mathrm{O}_{3}\right)$. Electrochemical potentiodynamic curves revealed three different stages of the reaction, including anodic and cathodic processes, prepassivation section, and stable passivation stages. The self-corrosion potential ( $\mathrm{E}_{\mathrm{corr}}$ ) of alloys with $\mathrm{Ce}$ and $\mathrm{La}$ addition were a little bit more negative, hardly making a difference on corrosion occurrence. However, the corrosion current density $\left(\mathrm{I}_{\mathrm{corr}}\right)$ and passivation current density $\left(\mathrm{I}_{\mathrm{p}}\right)$ decreased by two-thirds and one-half respectively, which indicated a better corrosion resistant after adding rare earths. The recorded micrographs of corroded surface at different polarized points witnessed the formation of corrosion product film both on prepassivation and passivation stage. Moreover, the cross section of corrosion product film showed the coarse, loose film in $\mathrm{Sn}-0.7 \mathrm{Cu}-0.075 \mathrm{Al}$ solder and adherent, compact film in Ce (La)-containing solders, which further indicated an excellent anti-corrosion property.
\end{abstract}

Keywords: $\mathrm{Sn}-\mathrm{Cu}-\mathrm{Al}$ solder; rare earths; microstructure; corrosion

\section{Introduction}

Toxic $\mathrm{Pb}$ in $\mathrm{Sn}-\mathrm{Pb}$ solder swarmed into the waste streams of electronic industries in the past years, and restrictive regulations have been worked to make wide usage of a variety of lead-free solders possible [1,2]. The near eutectic $\mathrm{Sn}-\mathrm{Cu}$ alloy system is a suitable alternative due to its low cost and good mechanical properties [3,4]. Since lower brazing temperature is not necessary for wave soldering, $\mathrm{Sn}-\mathrm{Cu}$ solders have widely come into commercial use in that area $[5,6]$. However, microelectronic equipment meets the requirements against corrosive media, as a result, protecting ecosystems and human health from dissolved heavy metal content should be put on the agenda $[7,8]$. Hence, the study of corrosion behavior of $\mathrm{Sn}-\mathrm{Cu}$ alloys is imperative. 
Limited attention is paid on the corrosion properties about $\mathrm{Sn}-\mathrm{Cu}$ solders. Li et al. [9] examined the $\mathrm{E}_{\mathrm{corr}}$ and $\mathrm{I}_{\mathrm{P}}$ of $\mathrm{Sn}-\mathrm{Cu}$ alloy and reported that its corrosion resistance was similar to $\mathrm{Sn}-\mathrm{Ag}-\mathrm{Cu}$ and $\mathrm{Sn}-\mathrm{Ag}$ but better than $\mathrm{Sn}-\mathrm{Pb}$ solder. Gao et al. [8] revealed the different corrosion behaviors between $\mathrm{Sn}-0.75 \mathrm{Cu}$ solder and $\mathrm{Sn}-0.75 \mathrm{Cu} / \mathrm{Cu}$ joint with the former performed better. Some scientific research [10-12] found that intermetallics of Sn-Cu solders played an important role in the process of corrosion and their corrosion products. These corrosion products have been detected to evaluate their behaviors. Some studies focused on the whisker growth of $\mathrm{Sn}-\mathrm{Cu}$ alloy in various corrosion environment. The results presented that the whisker growth direction and the whisker growth rate of $\mathrm{Sn}-\mathrm{Cu}$ alloy were detected in $3.5 \% \mathrm{NaCl}$ aq. added with high and low electric field [13], while copper-oxide whiskers could be observed to plated on copper substrates when exposed Sn-Cu alloy coatings to elevated temperature and humidity conditions [14].

Effect of rare earth (Ce and La) on microstructures and mechanical properties of lead-free solders has been summarized sufficiently [15-25]: the finer microstructure, higher tensile strength, and better solderability had been achieved in $\mathrm{Sn}-\mathrm{Ag}-\mathrm{Cu}, \mathrm{Sn}-\mathrm{Ag}, \mathrm{Sn}-\mathrm{Zn}$, and $\mathrm{Sn}-\mathrm{Cu}$ solders which included Ce or La. On the other hand, RE alloying had been proved to be an effective method of optimizing the corrosion performance of some steel, aluminum, and magnesium alloys [26,27], but rarely enough on lead-free solders in corrosion behavior.

Recently, Yang et al. [28] reported that $\mathrm{Sn}-0.7 \mathrm{Cu}-0.075 \mathrm{Al}$ had superior mechanical properties due to the refined microstructure, the dispersed IMC and the uniform stress distribution. However, when it came to corrosion resistance, the directionally solidified method was used to prepare alloys with different microstructure arrays, and found that the corrosion resistance of Sn-Cu solder which characterized by coarser cellular microstructure array was better than the finest cellular microstructure, which was reported by Osório et al. [29-31]. Based on trace element aluminum leading to superior mechanical properties, the $\mathrm{Sn}-0.7 \mathrm{Cu}-0.075 \mathrm{Al}$ alloy was selected as the matrix alloy.

The main purpose of this work was to demonstrate the effect of the rare earth Ce and La on the electrochemical behaviors of the $\mathrm{Sn}-0.7 \mathrm{Cu}-0.075 \mathrm{Al}$ alloy, especially in corrosion potential, polarization behavior, and passivate phenomenon. At the end of this article, the mechanism through rare earth addition was discussed, which was based on the results of the experiment.

\section{Experimental Procedure}

\subsection{Materials and Samples Preparation}

The basic alloys Sn-0.7Cu-0.075 Al (denoted as SCA in this paper) were prepared by commercial starting materials Sn (99.9\%, $38 \mu \mathrm{m}$ mean grain size), $\mathrm{Cu}(99.85 \%, 10 \mu \mathrm{m}$ mean grain size), and $\mathrm{Al}$ $(99.7 \%, 3 \mu \mathrm{m}$ mean grain size) powders. In order to obtain uniform component of Sn-0.7Cu-0.075Al alloy, a procedure that solve the problem of strong repulsive force in both Al-Sn and Al-Cu binary system had been used. The elemental powders of nominal composition were mixed in a planetary ball mill (90 r/min, $20 \mathrm{~min}, \mathrm{BXQM}-2 \mathrm{~L}$, Nanjing, China), and then were compacted to an ingot of $10 \mathrm{~g}$ at a pressure of $15 \mathrm{MPa}$ each sample. Afterwards, the ingots added with Ce (>99.9 wt \%) and La $(>99.9 \mathrm{wt} \%)$ respectively were solution-treated and homogenized by melting in a vacuum arc remelting furnace for four times to produce Sn-0.7Cu-0.075Al-0.25Ce (SCAC), Sn-0.7Cu-0.075Al-0.25La (SCAL).

\subsection{Microstructural Observation}

Specimens were mounted in epoxy. The mounted specimens were grinded and polished according to standard metallographic techniques. The pregrinding processes of SCA, SCAC, and SCAL alloys were caused by waterproof abrasive papers with various degree of roughness from grit 1000 to grit 5000. A silk and a $\mathrm{SiO}_{2}$-containing polishing solution were used to polish without being etched because the $\mathrm{SiO}_{2}$-containing polishing solution was alkalescent. The microstructures were examined by optical microscope (OM, MDS400, Chongqing, China) and scanning electron microscopy (SEM, Hitachi S-3400, Tokyo, Japan) with the energy dispersive X-ray (EDX) spectrom was used to determine 
the rare earth compositions at selected areas. The phases of the alloy samples were identified using an $\mathrm{X}$-ray diffraction (XRD, Rigaku D/Max 2500V, Tokyo, Japan) using $\mathrm{CuK} \alpha$ radiation, operating at $40 \mathrm{KV}$, $200 \mathrm{~mA}$ and a scanning rate of $8\left(^{\circ}\right) / \mathrm{min}$ at diffraction angle $2 \theta$ from 20 to $90^{\circ}$.

\subsection{Electrochemical Corrosion}

Before electrochemical potentiodynamic measurements, the samples were machined to be $10 \times 10 \times 5 \mathrm{~mm}$ using electric spark cutting, and ground to a 5000 grit surface finish using silicon carbide paper, followed by distilled water washing and air drying. Then the selected samples were positioned into a glass cell with a circular $1.0 \pm 0.02 \mathrm{~cm}^{2}$ surface immersed in a naturally aerated and stagnant solution $(250 \mathrm{~mL})$ of $3.5 \mathrm{wt} \% \mathrm{NaCl}$ at room temperature $\left(25.0 \pm 0.1^{\circ} \mathrm{C}\right)$. A working electrode (i.e., samples), a platinum counter-electrode and a saturated calomel reference electrode (SCE) were designed to test the potentiodynamic polarization curves $\log \mathrm{I}=f(\mathrm{E})$ which were determined by a wide range from $-900 \mathrm{mV}$ to $1700 \mathrm{mV}$ (vs. SCE), at the scan rate of $2 \mathrm{mV} / \mathrm{s}$. The characterization of corrosion products, including the microstructure and the interface morphology, were investigated with a scanning electron microscopy (SEM, Hitachi S-3400, Tokyo, Japan), an energy dispersive spectroscopy (EDS) and a X-ray diffractometer (XRD, Rigaku D/Max 2500V, Tokyo, Japan) when polarized to different points marked at polarization curves. The corrosion rate is calculated by the following formula

$$
\text { Corrosion rate }=\frac{\mathrm{A} \times \mathrm{I}_{\text {corr }}}{\mathrm{n} \times \mathrm{F} \times \rho} \times 87600
$$

The unit of corrosion rate is $\mathrm{mm} / \mathrm{a}$; $\mathrm{A}$-relative atomic weight of the sample; $\mathrm{I}_{\mathrm{corr}}$-corrosion current density, its unit is $\mathrm{A} \cdot \mathrm{cm}^{-2} ; \mathrm{n}$-number of electron transfer in electrochemical reaction; $\mathrm{F}$-constant, 26.8; $\rho$-density of alloy, its unit is $\mathrm{g} \cdot \mathrm{cm}^{-3}$.

\section{Results and Discussion}

\subsection{Microstructural Characterization}

Figure 1 showed the microstructure of $\mathrm{Sn}-0.7 \mathrm{Cu}-0.075 \mathrm{Al}$ lead-free solders by light microscopy and the effects of adding cerium and lanthanum. As was shown in Figure 1a, the microstructure of $\mathrm{Sn}-0.7 \mathrm{Cu}-0.075 \mathrm{Al}$ solder consisted of a matrix single phase and eutectic structure. The XRD results in Figure 2 confirmed that the matrix single phase (bright region in Figure 1a) was $\beta$-Sn, and the eutectic structure (dark region in Figure 1a) was $\mathrm{Cu}_{6} \mathrm{Sn}_{5} / \mathrm{Sn}$ eutectic. This result matched those with the previous literature that researched on $\mathrm{Sn}-0.7 \mathrm{Cu}$ alloy [32-34]. As for $\mathrm{Sn}-0.7 \mathrm{Cu}$ alloy adding $\mathrm{Al}$, the existence of $\mathrm{Al}$ depends on its content: the $\mathrm{Al}-\mathrm{Cu}$ binary compound is formed preferentially according to thermodynamics; very little $\mathrm{Al}$ atom solid solutes in $\mathrm{Sn}$ matrix could be possible based on the Al-Sn phase diagram; another situation could be Al particles exist in Sn matrix as the reference [35] recorded. Yang et al. [28] noted that the $\mathrm{IMC} \mathrm{Cu}_{6} \mathrm{Sn}_{5}$ in the $\mathrm{Sn}-0.7 \mathrm{Cu}$ alloy would partly transform into $\mathrm{Al}_{2} \mathrm{Cu}$ when aluminum content exceeded $0.05 \mathrm{wt} \%$, but according to Lai et al. [36], the $\mathrm{Al}_{2} \mathrm{Cu}$ was not detected when aluminum content was under $0.15 \mathrm{wt} \%$. In this study, when aluminum content was $0.075 \mathrm{wt} \%$, the $\mathrm{Al}_{2} \mathrm{Cu}$ was not found by XRD, SEM and EDS technologies, and the reason could be that the trace $\mathrm{Al}$ atom solid soluted in $\mathrm{Sn}$ matrix.

According to Figure $1 b, c$, the changes of microstructure after the addition of Ce and La in the SCA alloy can be observed. With the addition of $\mathrm{Ce}$, finer and more uniform $\beta$-Sn grains had been obtained, the refined microstructure of $\mathrm{Cu}_{6} \mathrm{Sn}_{5}$ particles had been formed, and the directional tendency of grain growth emerged, as illustrated in Figure $1 \mathrm{~b}$. The effects of adding La were similar with adding Ce. Furthermore, with the addition of La, the region between the $\beta$-Sn grain boundaries which mainly made up of distributed $\mathrm{Cu}_{6} \mathrm{Sn}_{5}$ phase became slender (see Figure 1c). This was because rare-earth-containing particles worked as grain refiner during solidification. Some of rare-earth contained particles-such as $\mathrm{CeSn}_{3}, \mathrm{LaSn}_{3}$, and $\mathrm{CeO}_{2}$ - have been identified by other authors [18-23,37]. In this work, the square-like phase was speculated to be $\mathrm{CeO}_{2}$ by EDX/SEM, as illustrated in Figure 3a. The EDS result in Figure 3b 
confirmed the presence of oxygen and lanthanum, these square-like shape particles were identified to be $\mathrm{La}_{2} \mathrm{O}_{3}$.
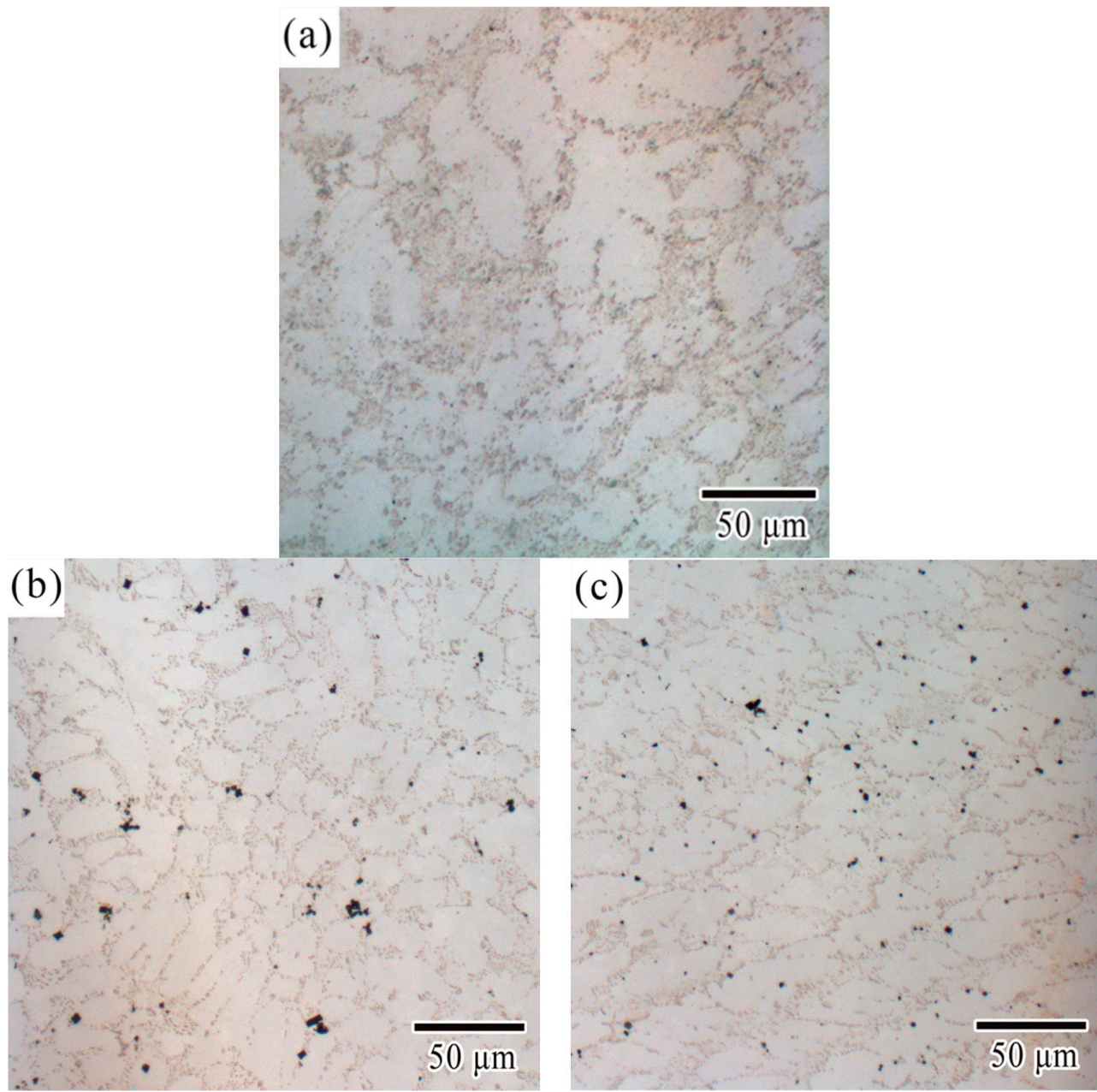

Figure 1. Microstructure of (a) SCA, (b) SCAC, and (c) SCAL solders by light microscopy.

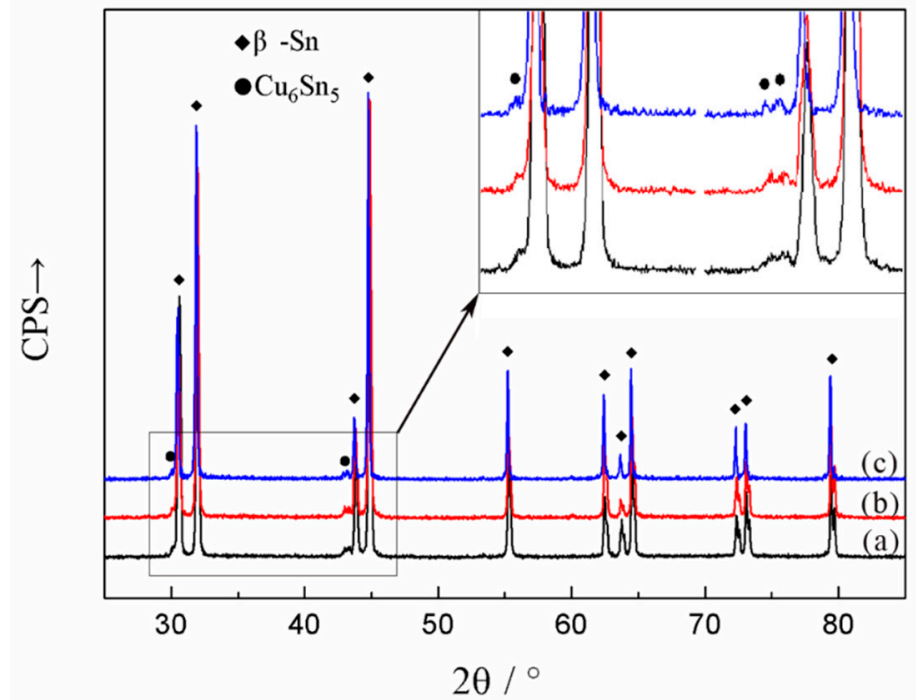

Figure 2. XRD diffraction patterns of (a) SCA, (b) SCAC, and (c) SCAL solders. 

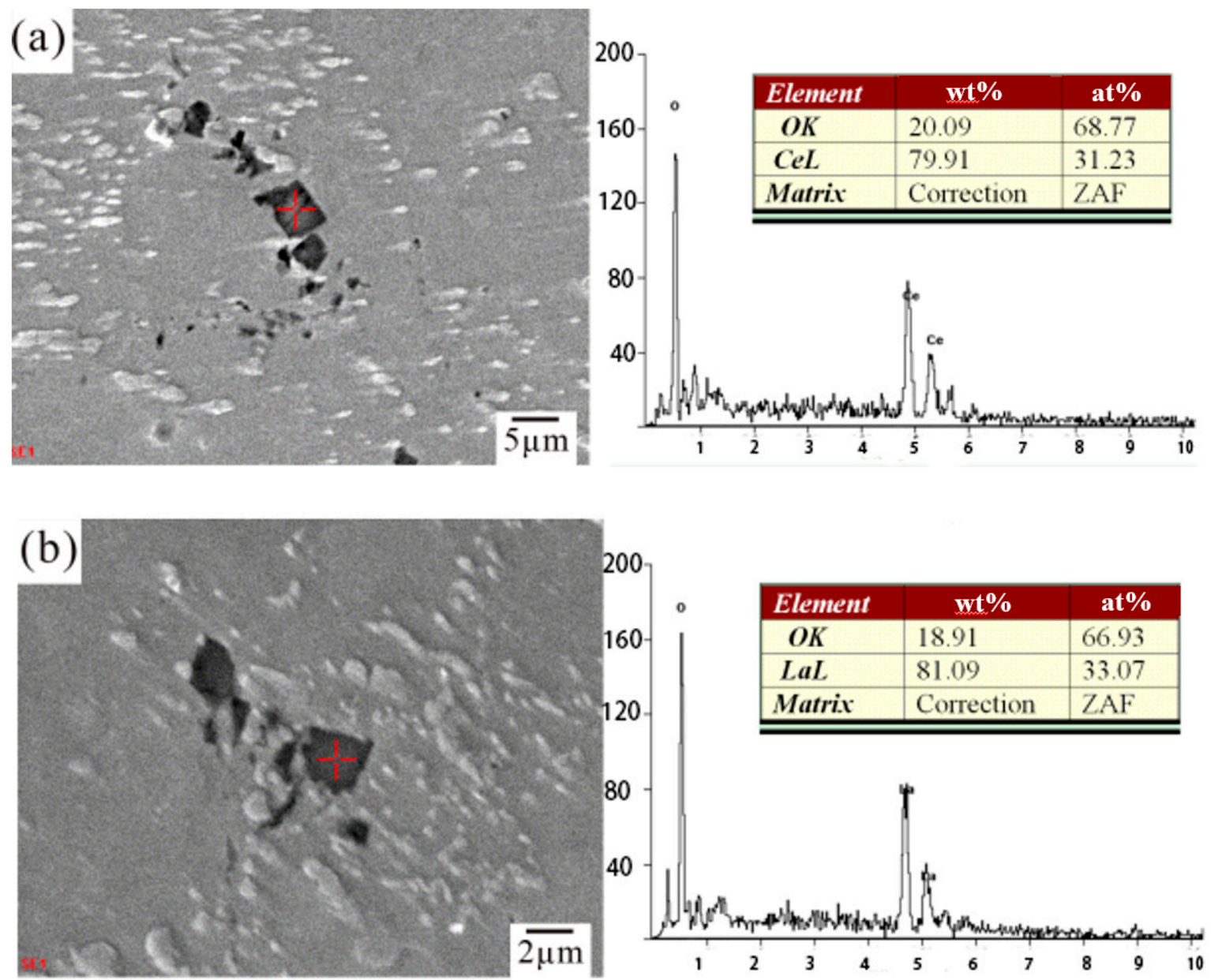

Figure 3. SEM images and EDS results of (a) SCAC and (b) SCAL solders.

\subsection{Electrochemical Corrosion Analysis}

The potentiodynamic polarization curves of SCA, SCAC, and SCAL solder samples in $3.5 \mathrm{wt} \%$ $\mathrm{NaCl}$ solution at room temperature are reported in Figure 4 . The corrosion potential $\left(\mathrm{E}_{\text {corr }}\right)$ and the corrosion current densities $\left(\mathrm{I}_{\text {corr }}\right)$ were obtained by Tafel's extrapolation using the CVIEW tools, as were shown in Table 1. The corrosion potential ( $\mathrm{E}_{\text {corr }}$ ) of SCA solder was $-639 \mathrm{mV}$ while the $\mathrm{E}_{\text {corr }}$ of SCAC and SCAL was $-685 \mathrm{mV}$ and $-718 \mathrm{mV}$, respectively. The self-corrosion potential became little more negative after adding $\mathrm{Ce}$ and $\mathrm{La}$, it can be explained by the more negative electronegativity of $\mathrm{Ce}$ and La. However, the corrosion current density $\left(\mathrm{I}_{\text {corr }}\right)$ of SCA decreased from $4.16 \times 10^{-7} \mathrm{~A} \cdot \mathrm{cm}^{-2}$ to $1.43 \times 10^{-7} \mathrm{~A} \cdot \mathrm{cm}^{-2}$ after adding Ce, and from $4.16 \times 10^{-7} \mathrm{~A} \cdot \mathrm{cm}^{-2}$ to $1.19 \times 10^{-6} \mathrm{~A} \cdot \mathrm{cm}^{-2}$ after adding La accordingly. The calculated long-time corrosion rate based on corrosion current density decreased from $0.009 \mathrm{~mm} /$ year to $0.004 \mathrm{~mm} /$ year. These results indicated that the rare earths Ce and La had a positive effect on the corrosion resistance of SCA solder. 


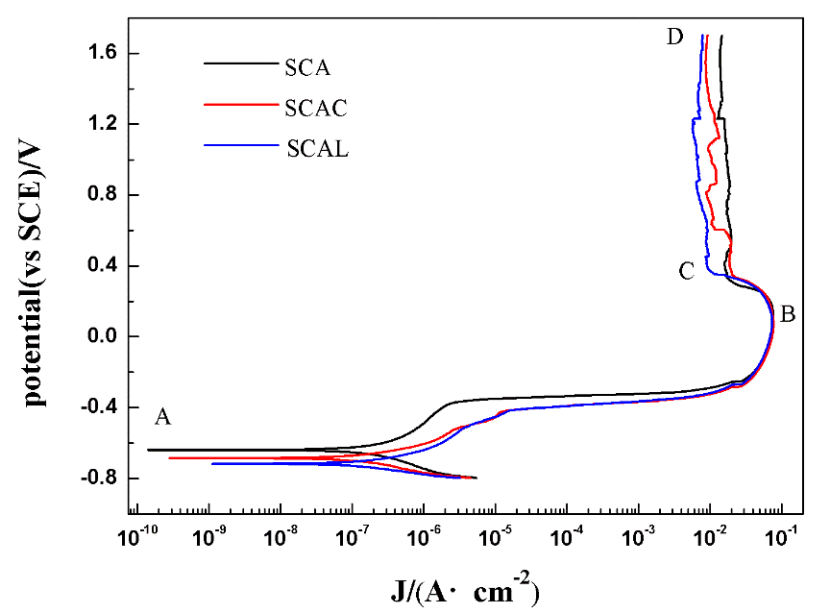

Figure 4. Polarization curves of SCA, SCAC, and SCAL solders in 3.5\% NaCl.

Table 1. Electrochemical parameters of SCA, SCAC, and SCAL solders in $3.5 \% \mathrm{NaCl}$ solution

\begin{tabular}{cccccccc}
\hline Material & $\begin{array}{c}\mathbf{E}_{\text {corr }} \\
(\mathbf{m V})\end{array}$ & $\begin{array}{c}\mathbf{I}_{\mathbf{c o r r}} \\
\left(\mathbf{A} \cdot \mathbf{c m}^{-2}\right)\end{array}$ & $\begin{array}{c}\mathbf{E}_{\mathbf{p p}} \\
(\mathbf{m V})\end{array}$ & $\begin{array}{c}\mathbf{I}_{\mathbf{c}} \\
\left(\mathbf{A} \cdot \mathbf{c m}^{-2}\right)\end{array}$ & $\begin{array}{c}\mathbf{E}_{\mathbf{p}} \\
(\mathbf{m V})\end{array}$ & $\begin{array}{c}\mathbf{I}_{\mathbf{p}} \\
\left(\mathbf{A} \cdot \mathbf{c m}^{-2}\right)\end{array}$ & $\begin{array}{c}\text { Corrosion Rate } \\
(\mathbf{m m} / \mathbf{a})\end{array}$ \\
\hline SCA & -639 & $4.16 \times 10^{-7}$ & 113 & $7.69 \times 10^{-2}$ & 334 & $1.40 \times 10^{-2}$ & 0.009 \\
SCAC & -685 & $1.43 \times 10^{-7}$ & 71 & $7.76 \times 10^{-2}$ & 344 & $0.87 \times 10^{-2}$ & 0.004 \\
SCAL & -718 & $1.19 \times 10^{-7}$ & 84 & $7.41 \times 10^{-2}$ & 357 & $0.75 \times 10^{-2}$ & 0.004 \\
\hline
\end{tabular}

\subsubsection{Transformation from Cathodic Polarization to Anodic Polarization}

Before the transformation, the dissolved oxygen reduction reaction and hydrogen evolution reaction on the cathode occurred. Then the current density began to increase rapidly at point $A$, which can be defined as the transformation. At this stage, the cathodic polarization was characterized by dissolved oxygen reduction and hydrogen evolution reaction, which was reported in Gao's study [8]. The first step was that oxygen dissolved until it was completely consumed

$$
\mathrm{O}_{2}+4 \mathrm{e}^{-}+\mathrm{H}_{2} \mathrm{O} \rightarrow 4 \mathrm{OH}^{-}
$$

Then hydrogen bubbles appeared ceaselessly

$$
2 \mathrm{H}_{2} \mathrm{O}+2 \mathrm{e}^{-} \rightarrow \mathrm{H}_{2}+2 \mathrm{OH}^{-}
$$

It can be seen from the reaction that there was no corrosion products gathering on the cathode, and the surface was observed to be bright at the end of the transformation.

\subsubsection{Active/Passive Transition Stage}

The active reaction from point $\mathrm{A}$ to point $\mathrm{B}$ occurred when anodic dissolution took. At this section, the current density continued to escalate dramatically since active Sn dissolved into tin ion. According to Mohran's study [38], Sn was betatopic as following reaction took place

$$
\mathrm{Sn}-2 \mathrm{e}^{-} \rightarrow \mathrm{Sn}^{2+}
$$

then $\mathrm{Sn}^{2+}$ further oxidized to $\mathrm{Sn}^{4+}$

$$
\mathrm{Sn}^{2+}-2 \mathrm{e}^{-} \rightarrow \mathrm{Sn}^{4+}
$$

After anodic dissolution, the current density tended to decrease from starting over point B. Then the prepassivation section began. The potential and current density at point $B$ was named as the prepassivation potential $\left(E_{p p}\right)$ and critical current density $\left(I_{c}\right)$ respectively. A conclusion could be drawn from Table 1 that, although $C e$ and La addition hardly changed the $I_{c}$ of SCA, the $E_{p p}$ had been 
effectively reduced which suggested the passivation capability had been improved. Figure 5 showed the corroded surface morphologies of SCA, SCAC, and SCAL solder samples when polarized up around to point B. Figure 5a,b obviously offered an evidence to show the existence of a thin oxide-film that did not completely dissolve. According to the theory of metal passivation, the thin oxide-film should be compact enough to insulate the metal from etching solution mechanically. However, it dissolved fast, and the reason was that it was too thin to overcome the increase of the potential. Once the oxide film broke down, the new uncorroded Sn phase was exposed to the solution, generating an abhurite adsorbing on the surface, especially on the pits of the surface. The adsorbed corrosion products hindered the further corrosion of metals. Thus, the slight reduction of the current density between point $B$ and point $C$ should be the consequence from comprehensive function of multiple factors that mentioned above. Similar effects after adding Ce and La on the surface morphology of SCA could be observed in Figure 5c,e, and the hollows seemed to be the result of dissolved anodic Sn. However, it was interesting that there was no dissolution of oxide film. Moreover, the plate-like corrosion products generated directly on the surface after anodic Sn dissolved. That might explain why SCAC and SCAL solders prepassivated earlier.
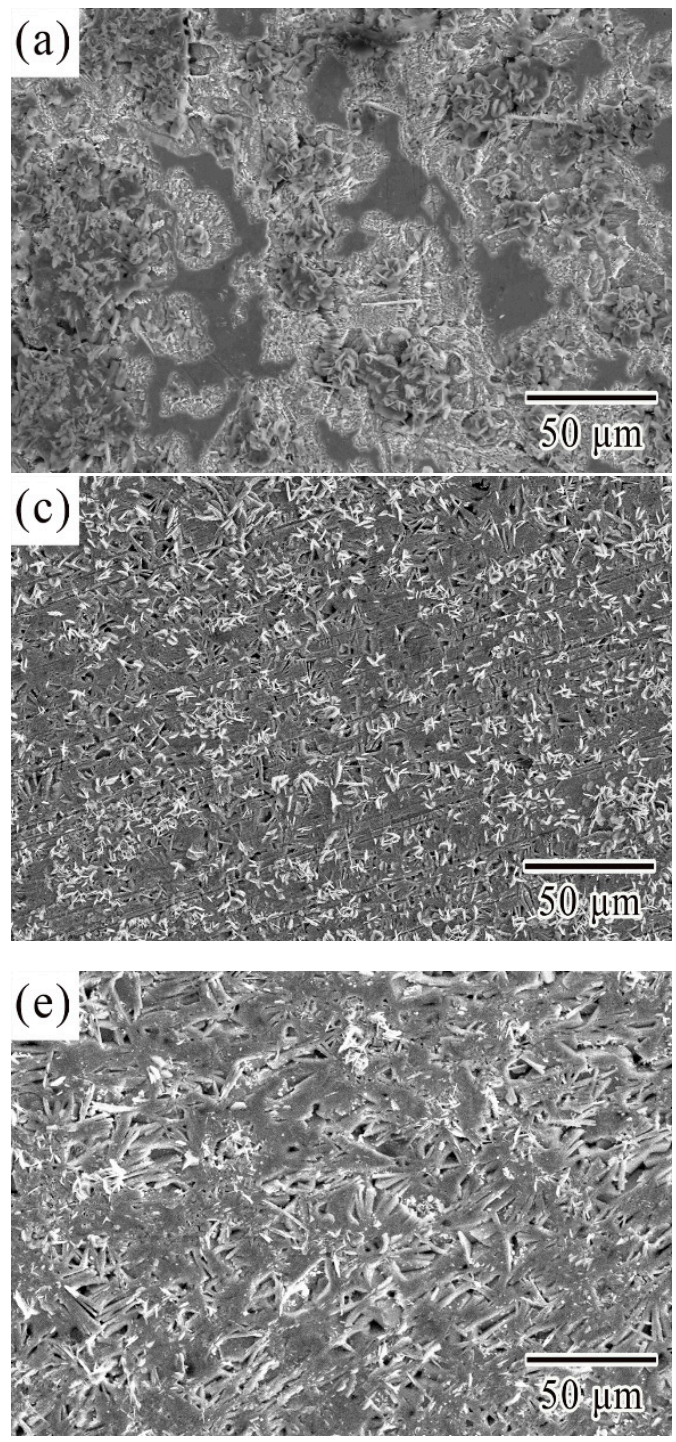
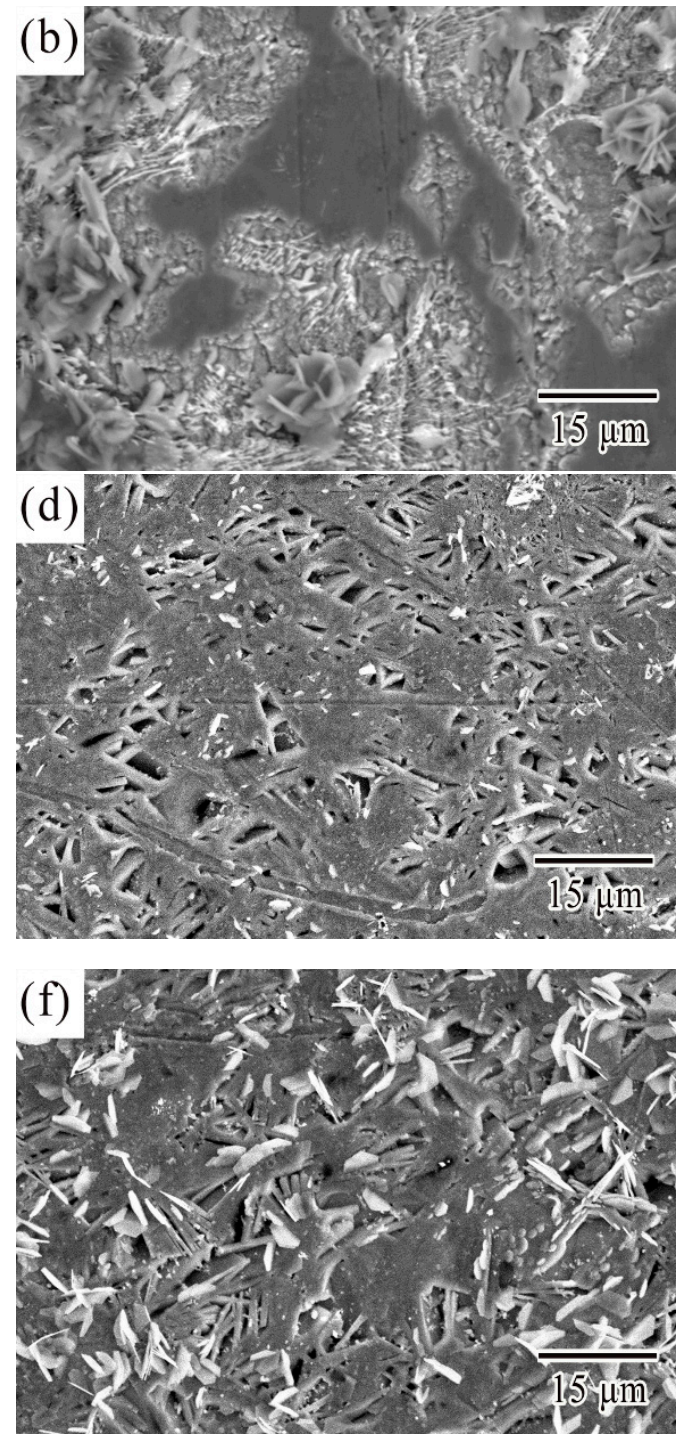

Figure 5. Illustrated the surface morphology of (a,b) SCA, (c,d) SCAC, and (e,f) SCAL solders when the samples polarized up to point $B$. 


\subsubsection{Stable Passivation Stage}

When the samples polarized up to point $C$, the passivation state became stable. A trend in Figure 4 showed the current densities that began last lessen were leveling off. At the initial stage of stable passivation, the corrosion products had generated enough to cover the surface of samples, as were shown in Figure 6, and the further corrosion transformed into a harder form that made current density steady-going: corrosive ions had to transfer through corrosion product film to contact unexposed metal.

The average current density from point $C$ to point $D$ was identified as passivation current density $\left(I_{p}\right)$ in this study. The highest passivation current density $\left(I_{p}\right) 1.40 \times 10^{-2} \mathrm{~A} \cdot \mathrm{cm}^{-2}$ was attained for the sample from SCA solder. By contrast, the $I_{p}$ value of the SCAC and SCAL solders were $0.87 \times 10^{-2} \mathrm{~A} \cdot \mathrm{cm}^{-2}$ and $0.75 \times 10^{-2} \mathrm{~A} \cdot \mathrm{cm}^{-2}$ respectively, about half of the SCA solder's. Figure $6 \mathrm{a}$ illustrated the excessive gap in corrosion product film. The excessive gap enhanced the ion exchange ratio, and the exposed metal still can be seen in Figure 6b. That explained the higher passivation current density $\left(\mathrm{I}_{\mathrm{p}}\right)$ of SCA solder. In comparison, the addition of Ce and La contributed to the compact corrosion product film, as was shown in Figure 6c,e, while the exposed metal hardly can be seen in Figure 6d,f.
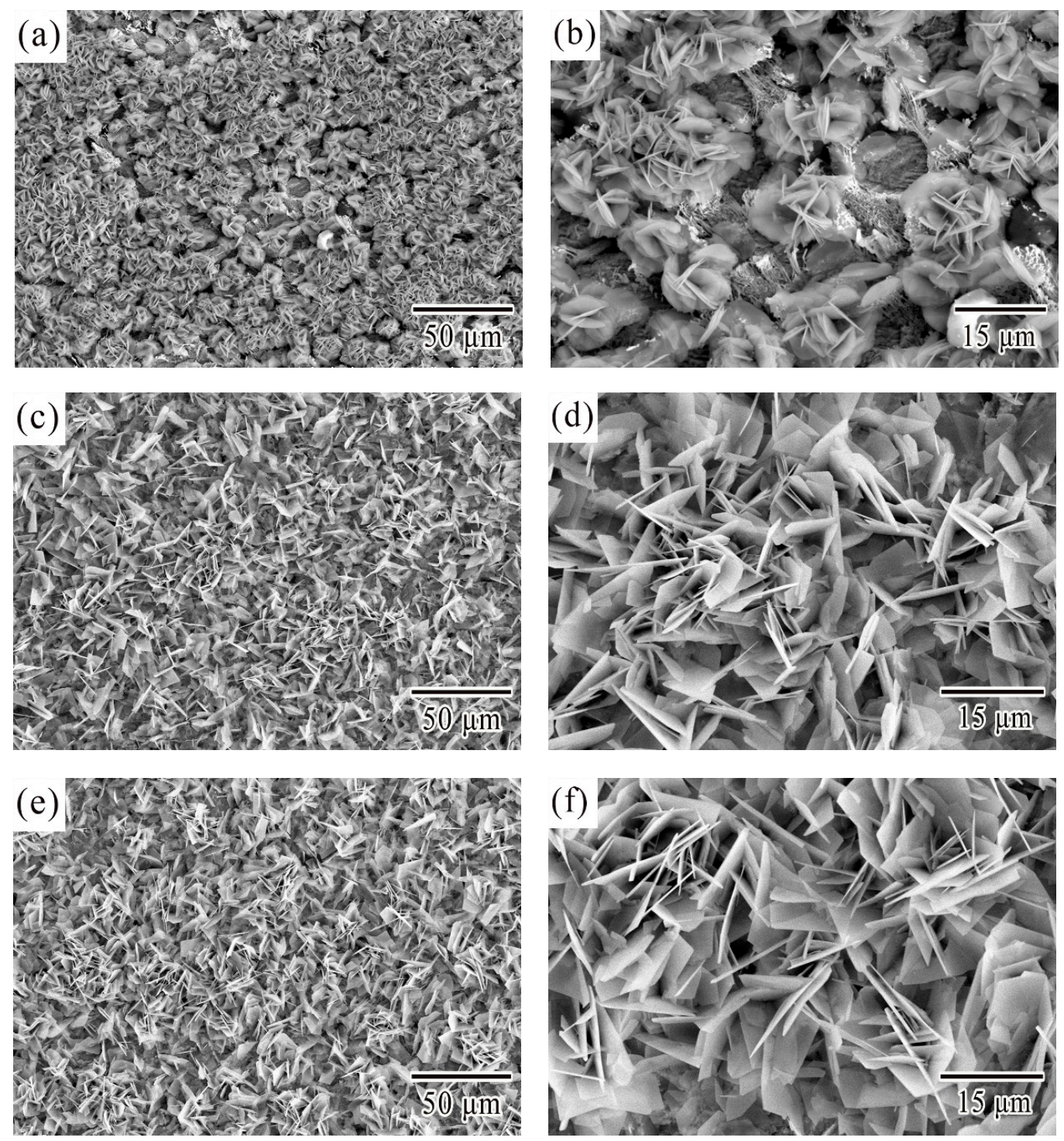

Figure 6. Micrographs of corroded surface of $(\mathbf{a}, \mathbf{b})$ SCA, $(\mathbf{c}, \mathbf{d})$ SCAC, and (e,f) SCAL solders when polarized to point $\mathrm{C}$. 
Figure 7 showed the different micrographs of corroded surface after electrochemical potentiodynamic measurements. The results showed that the similar morphology of corrosion products were obtained from SCA, SCAC, and SCAL solders when polarized to point $\mathrm{D}$. The corrosion products were platelet-like shape and were likely to form clusters with different orientations. The XRD patterns for the corrosion products of SCA, SCAC, and SCAL solders after electrochemical potentiodynamic measurements were showed in Figure 8. No peak of pure Sn was detected, which confirmed that the surface of solders was full of corrosion products. The dominant peaks were retrieved, and the corrosion products were proved to be $\mathrm{Sn}_{3} \mathrm{O}(\mathrm{OH})_{2} \mathrm{Cl}_{2}$. The equation gives an interpretation to the formation of this tin oxy-hydroxide chloride that had already been reported $[8,30]$

$$
3 \mathrm{Sn}+4 \mathrm{OH}^{-}+2 \mathrm{Cl}^{-} \rightarrow \mathrm{Sn}_{3} \mathrm{O}(\mathrm{OH})_{2} \mathrm{Cl}_{2}+\mathrm{H}_{2} \mathrm{O}
$$

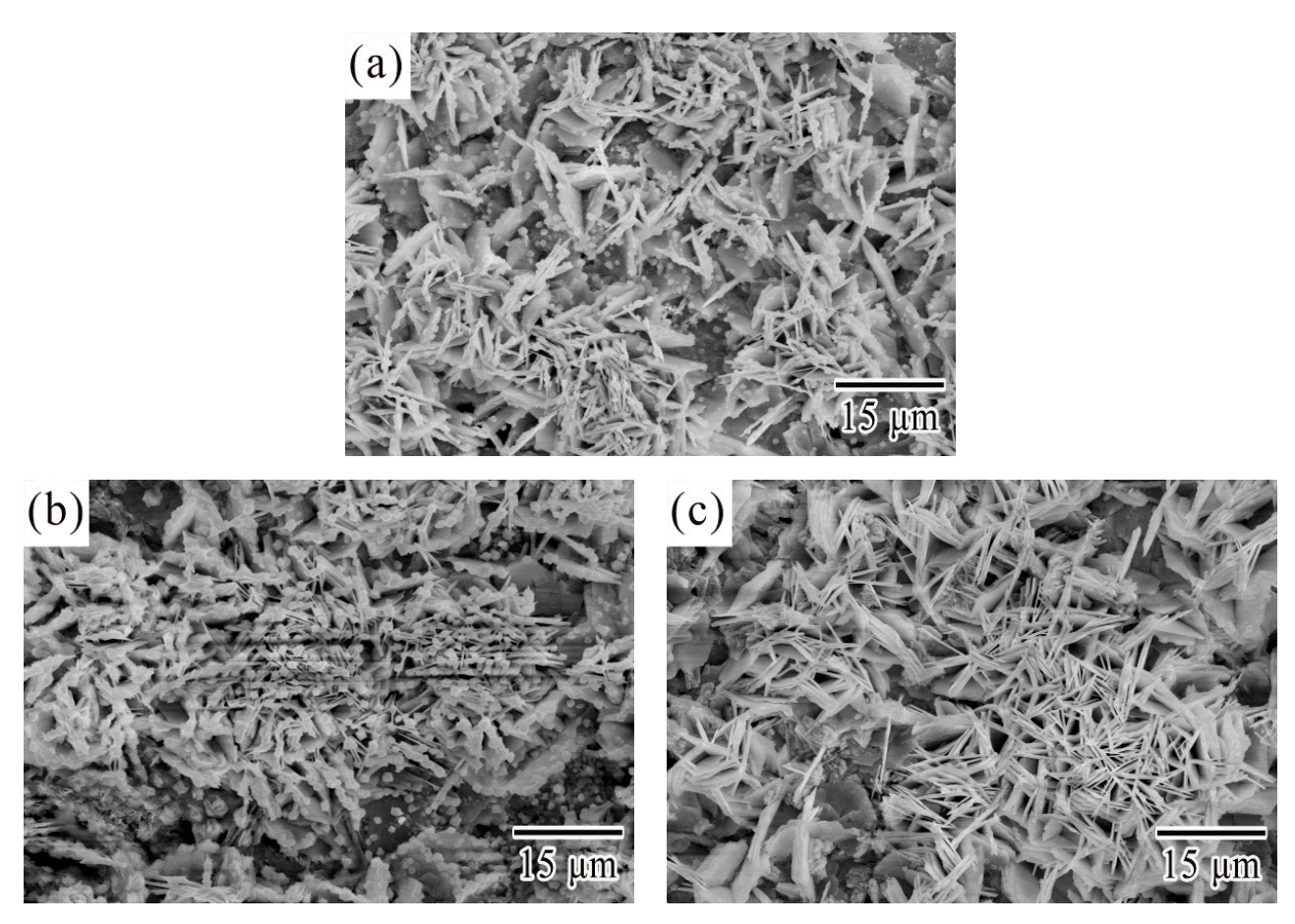

Figure 7. Micrographs of corroded surface of (a) SCA, (b) SCAC, and (c) SCAL solders when polarized to point D.

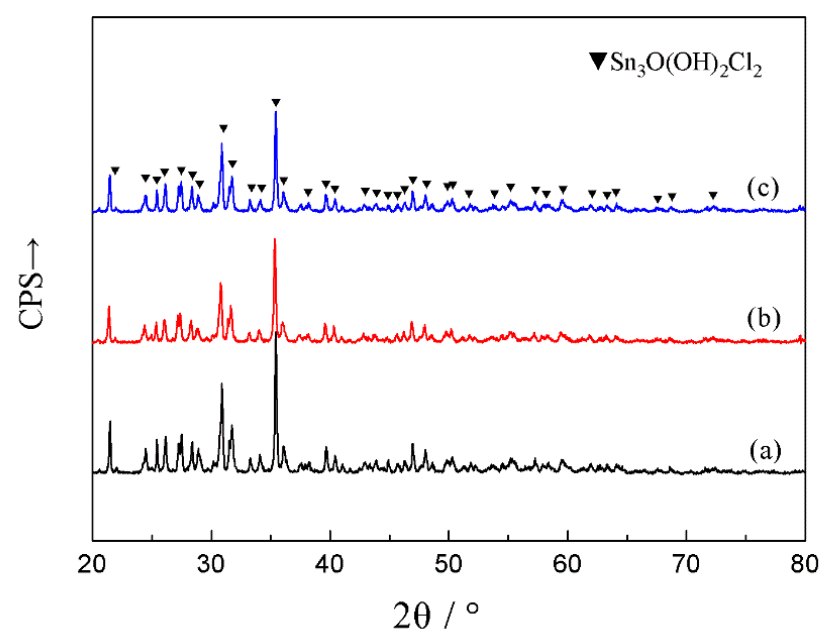

Figure 8. XRD diffraction patterns of corrosion products at surface when polarized to point D: (a) SCA, (b) SCAC, and (c) SCAL solders. 
In order to reveal the differences between SCA solder and rare earth-adding solders from a macroscopic view, the cross sections of these solders had been captured in Figure 9. In Figure 9a, on one hand, the structure of corrosion product film was separated into two parts, and thus the formative gap would recede the adhesion strength of the outer part. On the other hand, corrosive chlorium that transferred through the looser structure would cause further corrosion, which was shown by red encircled regions. However, with the addition of Ce and La (see Figure 9b,c), the structure of corrosion product film was integral, and the film tightly adhered to the surface. This indicated a greater passivation property in SCAC and SCAL solders, with the SCAL solder being best. The corresponding result was found in literature [39], which said that the $\mathrm{CeO}_{2}$ in $\mathrm{Sn}-\mathrm{Ag}$ solder brought in a more adherent, compact, and finer sheet-like structure of corrosion products which created a better passivation property.

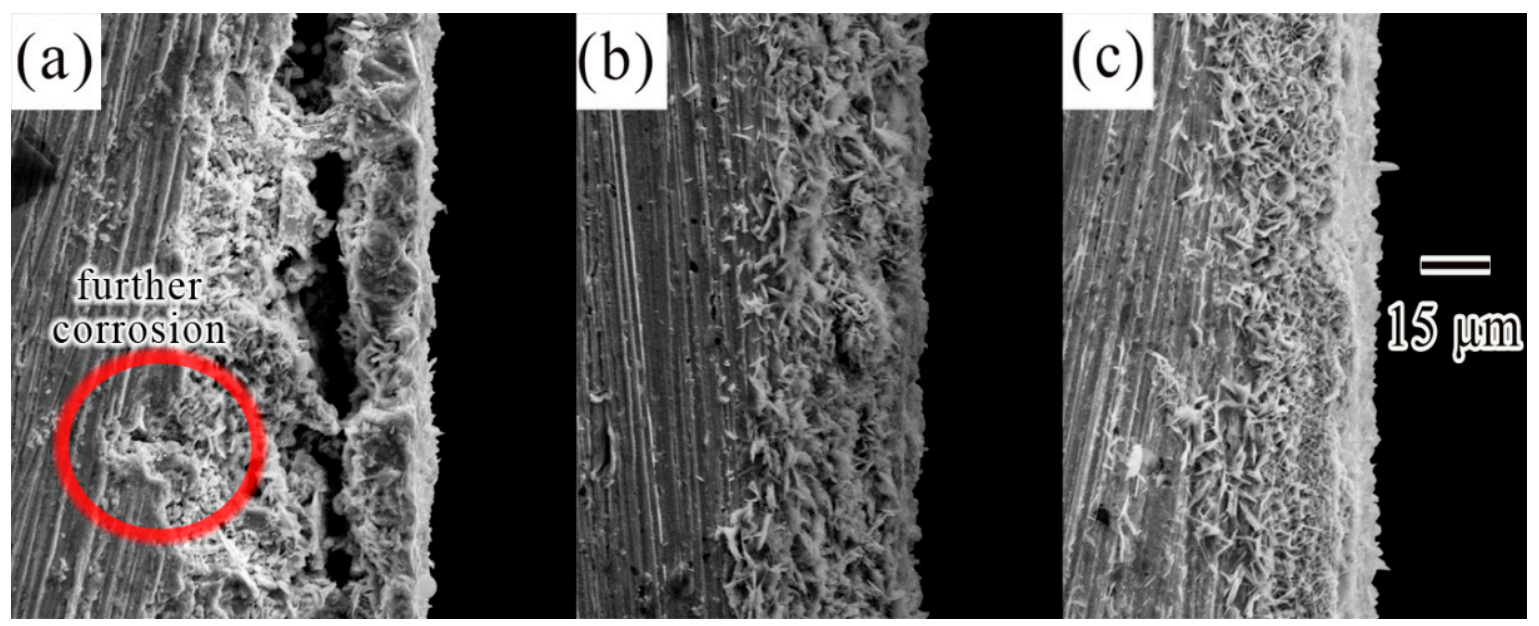

Figure 9. SEM images obtained from the cross section of (a) SCA, (b) SCAC, and (c) SCAL solders after tests.

A schematic diagram was depicted to illustrate the action mechanism of better corrosion resistance and better passivation property of SCAC and SCAL solders, as shown in Figure 10. Abundant corrosion microcells exist in the metal substrate. Every microcell is favorable with $\beta$-Sn serving as cathode and $\mathrm{Cu}_{6} \mathrm{Sn}_{5}$ as anode. As mentioned above, the finer $\beta$-Sn grains and homogeneously distributed $\mathrm{Cu}_{6} \mathrm{Sn}_{5}$ particles were formed concurrently, intermingled with the $\mathrm{CeO}_{2}\left(\mathrm{La}_{2} \mathrm{O}_{3}\right)$. As a result, the cathode/anode area ratio of the electrochemical cell is reduced, thus the corrosion rate of galvanic corrosion is inhibited. Furthermore, since the standard potential of $\mathrm{CeO}_{2}\left(\mathrm{La}_{2} \mathrm{O}_{3}\right)$ is more positive than $\beta-\mathrm{Sn}$, a fraction of $\mathrm{Ce}^{4+}$ $\left(\mathrm{La}^{3+}\right)$ ions will release from $\mathrm{CeO}_{2}\left(\mathrm{La}_{2} \mathrm{O}_{3}\right)$ particles into the solution [40]. Originally, the platelet-like shape corrosion products $\mathrm{Sn}_{3} \mathrm{O}(\mathrm{OH})_{2} \mathrm{Cl}_{2}$ are inclined to cluster together on the metal substrate surface, these clusters are relatively free to develop in the $\mathrm{NaCl}$ solution environment, and finally cause the hole forming in the gap of the clusters. However, with the $\mathrm{Ce}^{4+}\left(\mathrm{La}^{3+}\right)$ ions dissociated in the gaps, their strong absorptive capacity restrains the vacancy condensation of the clusters. Due to the $\mathrm{Ce}^{4+}$ $\left(\mathrm{La}^{3+}\right)$ ions acting as the surface modifier, the structure of corrosion products become adherent and compact, which effectively prevents the $\mathrm{Cl}^{-}$from passing through the product layer to further corrode the material [41,42]. 


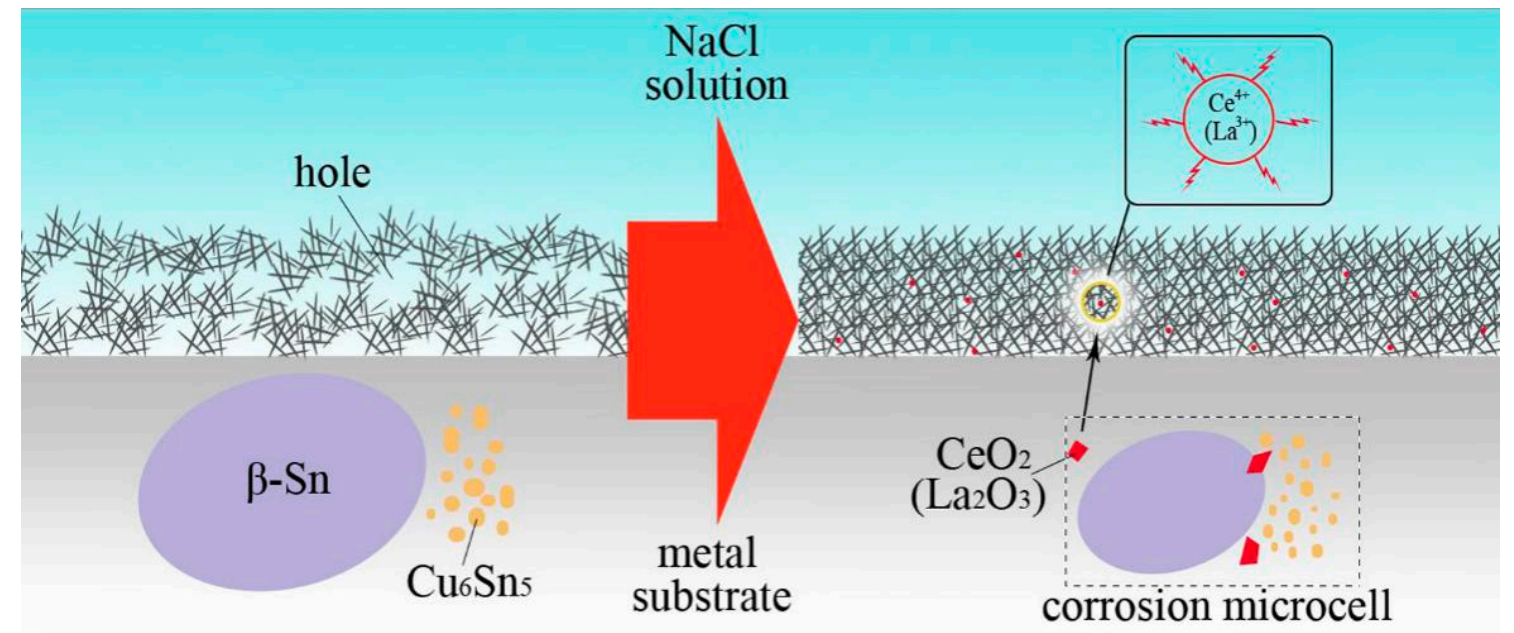

Figure 10. Schematic diagram of $\mathrm{CeO}_{2}\left(\mathrm{La}_{2} \mathrm{O}_{3}\right)$ inhibiting the galvanic corrosion and $\mathrm{Ce}^{4+}\left(\mathrm{La}^{3+}\right)$ ions restraining the hole of corrosion products.

\section{Conclusions}

The microstrcture of $\mathrm{Sn}-0.7 \mathrm{Cu}-0.075 \mathrm{Al}$ solder alloy consisted of $\beta-\mathrm{Sn}$ and $\mathrm{Cu}_{6} \mathrm{Sn}_{5} / \mathrm{Sn}$ eutectic, and $\mathrm{Al}_{2} \mathrm{Cu}$ was not found with the addtion of $\mathrm{Al}$, the trace $\mathrm{Al}$ atoms may have solid soluted in the $\mathrm{Sn}$ matrix. With the addtion of $\mathrm{Ce}$ and $\mathrm{La}$, the square-like $\mathrm{CeO}_{2}$ and $\mathrm{La}_{2} \mathrm{O}_{3}$ phases were generated dispersively, which lead to the refined grains of $\mathrm{Sn}-0.7 \mathrm{Cu}-0.075 \mathrm{Al}$ solder alloy. Furthermore, a directional tendency of grain growth emerged.

The self-corrosion potential of $\mathrm{Sn}-0.7 \mathrm{Cu}-0.075 \mathrm{Al}$ solder alloy became little more negative than before after adding Ce and La. However, the corrosion current density $\left(\mathrm{I}_{\text {corr }}\right)$ values of $\mathrm{Ce}(\mathrm{La})$-containing solders decreased up about three times. The phenomenon that a more adherent, compact and finer sheet-like structure of corrosion products forms after adding Ce and La should be noticed. By contrast, the corrosion product film of $\mathrm{Sn}-0.7 \mathrm{Cu}-0.075 \mathrm{Al}$ was coarse and loosely adherent to the surface, which lead to passivation current density (Ip) reduced by half at the stage of passivation. All the evidence indicated that a better corrosion property showed up with the addition of $\mathrm{Ce}$ and $\mathrm{La}$ in $\mathrm{Sn}-0.7 \mathrm{Cu}-0.075 \mathrm{Al}$ solder alloy, with the La-containing solder being best.

Author Contributions: Conceptualization, W.Y. and Y.Z.; Methodology, W.Y. and Z.D.; Software, Z.D. and Q.L.; Validation, Z.D., Q.L. and Y.L.; Formal Analysis, W.Y. and Z.D.; Investigation, W.Y., Y.L. and Z.D.; Resources, Y.Z., Y.L., S.Y., J.F. and X.W.; Data Curation, W.Y. and Z.D.; Writing-Original Draft Preparation, W.Y. and Z.D.; Writing-Review \& Editing, W.Y.; Visualization, Y.Z.; Supervision, W.Y.; Project Administration, Y.Z.; Funding Acquisition, Y.Z., J.F. and X.W.

Funding: This research was funded by by [the National Key R\&D Program of China] grant number [2016YFB0301400, 2018YFC0809105, 2018YFC0809100], [the Guangxi Natural Science Foundation] grant number [2018GXNSFDA050008], [the National Natural Science Foundation of China] grant number [51761002], [the Training Plan of High-Level Talents of Guangxi University (2015)], [Middle-aged and young teachers in colleges and universities in Guangxi Basic Ability Promotion Project] grant number [2018KY0038] and [the science and technology plan projects of Shenzhen Entry-Exit Inspection and Quarantine Bureau] grant number [SZ2017001).

Conflicts of Interest: The authors declare no conflict of interest.

\section{References}

1. Suganuma, K. Advances in lead-free electronics soldering. Curr. Opin. Solid St. Mater. Sci. 2001, 5, 55-64. [CrossRef]

2. Abtew, M.; Selvaduray, G. Lead-free solders in microelectronics. Mater. Sci. Eng. Rep. 2000, $27,95-141$. [CrossRef]

3. Suraski, D.; Seelig, K. The current status of lead-free solder alloys. IEEE Trans. Electron. Packag. Manuf. 2001, 24, 244-248. [CrossRef] 
4. Gourlay, C.M.; Nogita, K.; McDonald, S.D.; Nishimura, T.; Sweatman, K.; Dahle, A.K. A rheological assessment of the effect of trace level Ni additions on the solidification of Sn-0.7Cu. Scr. Mater. 2006, 54, 1557-1562. [CrossRef]

5. Sigelko, J.D.; Subramanian, K.N. Overview of lead-free solders. Adv. Mater. Process. 2000, 157, 47-48.

6. Harrison, M.R.; Vincent, J.H.; Steen, H.A.H. Lead-free reflow soldering for electronics assembly. Solder. Surf. Mt. Technol. 2001, 13, 21-38. [CrossRef]

7. Lim, S.R.; Schoenung, J.M. Human health and ecological toxicity potentials due to heavy metal content in waste electronic devices with flat panel displays. J. Hazard. Mater. 2010, 177, 251-259. [CrossRef] [PubMed]

8. Gao, Y.F.; Cheng, C.Q.; Zhao, J.; Wang, L.H.; Li, X.G. Electrochemical corrosion of Sn-0.75Cu solder joints in $\mathrm{NaCl}$ solution. Trans. Nonferrous Metal. Soc. China 2012, 22, 977-982. [CrossRef]

9. Li, D.; Conway, P.P.; Liu, C. Corrosion characterization of tin-lead and lead free solders in $3.5 \mathrm{wt} . \% \mathrm{NaCl}$ solution. Corros. Sci. 2008, 50, 995-1004. [CrossRef]

10. Osorio, W.R.; Peixoto, L.C.; Garcia, L.R.; Garcia, A.; Spinelli, J.E. The effects of microstructure and Ag3Sn and Cu6Sn5 intermetallics on the electrochemical behavior of Sn-Ag and Sn-Cu solder alloys. Int. J. Electrochem. Sci. 2012, 7, 6436-6452.

11. Osório, W.R.; Freire, C.M.; Caram, R.; Garcia, A. The role of Cu-based intermetallics on the pitting corrosion behavior of $\mathrm{Sn}-\mathrm{Cu}, \mathrm{Ti}-\mathrm{Cu}$ and Al-Cu alloys. Electrochim. Acta 2012, 77, 189-197. [CrossRef]

12. Tsao, L.C.; Chen, C.W. Corrosion characterization of Cu-Sn Intermetallics in $3.5 \mathrm{wt} . \% \mathrm{NaCl}$ solution. Corros. Sci. 2012, 63, 393-398. [CrossRef]

13. Moon, K.W.; Johnson, C.E.; Williams, M.E.; Kongstein, O.; Stafford, G.R.; Handwerker, C.A.; Boettinger, W.J. Observed correlation of $\mathrm{Sn}$ oxide film to $\mathrm{Sn}$ whisker growth in $\mathrm{Sn}-\mathrm{Cu}$ electrodeposit for Pb-free solders. J. Electron. Mater. 2005, 34, L31-L33. [CrossRef]

14. Horváth, B.; Illés, B.; Shinohara, T.; Harsányi, G. Copper-oxide whisker growth on tin-copper alloy coatings caused by the corrosion of Cu6Sn5 intermetallics. J. Mater. Sci. 2013, 48, 8052-8059. [CrossRef]

15. Dudek, M.A.; Sidhu, R.S.; Chawla, N.; Renavikar, M. Microstructure and mechanical behavior of novel rare earth-containing Pb-free solders. J. Electron. Mater. 2006, 35, 2088-2097. [CrossRef]

16. Wu, C.M.L.; Wong, Y.W. Rare-earth additions to lead-free electronic solders. J. Mater. Sci. Mater. Electron. 2007, 18, 77-91. [CrossRef]

17. Guo, F.; Zhao, M.K.; Xia, Z.D.; Lei, Y.P.; Li, X.Y.; Shi, Y.W. Lead-free solders with rare earth additions. JOM 2009, 61, 39-44. [CrossRef]

18. Zhasng, L.; Xue, S.B.; Gao, L.L.; Zeng, G.; Sheng, Z.; Chen, Y.; Yu, S.L. Effects of rare earths on properties and microstructures of lead-free solder alloys. J. Mater. Sci. Mater. Electron. 2009, 20,685-694. [CrossRef]

19. Dudek, M.A.; Chawla, N. Effect of rare-earth (La, Ce, and $\mathrm{Y}$ ) additions on the microstructure and mechanical behavior of Sn-3.9Ag-0.7Cu solder alloy. Metall. Mater. Trans. A 2010, 41, 610-620. [CrossRef]

20. Noh, B.I.; Choi, J.H.; Yoon, J.W.; Jung, S.B. Effects of cerium content on wettability, microstructure and mechanical properties of Sn-Ag-Ce solder alloys. J. Alloy. Compd. 2010, 499, 154-159. [CrossRef]

21. Wang, J.X.; Xue, S.B.; Han, Z.J.; Yu, S.L.; Chen, Y.; Shi, Y.P.; Wang, H. Effects of rare earth Ce on microstructures, solderability of $\mathrm{Sn}-\mathrm{Ag}-\mathrm{Cu}$ and $\mathrm{Sn}-\mathrm{Cu}-\mathrm{Ni}$ solders as well as mechanical properties of soldered joints. J. Alloy. Compd. 2009, 467, 219-226. [CrossRef]

22. Chen, W.X.; Xue, S.B.; Wang, H.; Hu, Y.; Wang, J.X. Effects of rare earth Ce on properties of Sn-9Zn lead-free solder. J. Mater. Sci. Mater. Electron. 2010, 21, 719-725. [CrossRef]

23. Wu, C.M.L.; Yu, D.Q.; Law, C.M.T.; Wang, L. The properties of Sn-9Zn lead-free solder alloys doped with trace rare earth elements. J. Electron. Mater. 2002, 31, 921-927. [CrossRef]

24. Liu, M.; Yang, W.; Ma, Y.; Tang, C.; Tang, H.; Zhan, Y. The electrochemical corrosion behavior of Pb-free Sn-8.5Zn-XCr solders in 3.5 wt.\% NaCl solution. Mater. Chem. Phys. 2015, 168, 27-34. [CrossRef]

25. Koleňák, R.; Kostolný, I. Study of direct bonding ceramics with metal using Sn2La solder. Adv. Mater. Sci. Eng. 2015, 2015, 1-13.

26. Forsyth, M.; Seter, M.; Tan, M.Y.; Hinton, B. Recent developments in corrosion inhibitors based on rare earth metal compounds. Corros. Eng. Sci. Technol. 2014, 49, 130-135. [CrossRef]

27. Montemor, M.F.; Simoes, A.M.; Carmezim, M.J. Characterization of rare-earth conversion films formed on the AZ31 magnesium alloy and its relation with corrosion protection. Appl. Surf. Sci. 2007, 253, 6922-6931. [CrossRef] 
28. Yang, L.; Zhang, Y.C.; Du, C.C.; Dai, J.; Zhang, N. Effect of aluminum concentration on the microstructure and mechanical properties of Sn-Cu-Al solder alloy. Microelectron. Reliab. 2015, 55, 596-601. [CrossRef]

29. Osório, W.R.; Spinelli, J.E.; Afonso, C.R.M.; Peixoto, L.C.; Garcia, A. Microstructure, corrosion behaviour and microhardness of a directionally solidified Sn-Cu solder alloy. Electrochim. Acta 2011, 56, 8891-8899. [CrossRef]

30. Osorio, W.R.; Freitas, E.S.; Spinelli, J.E.; Garcia, A. Electrochemical behavior of a lead-free Sn-Cu solder alloy in $\mathrm{NaCl}$ solution. Corros. Sci. 2014, 80, 71-81. [CrossRef]

31. Freitas, E.S.; Osorio, W.R.; Spinelli, J.E.; Garcia, A. Mechanical and corrosion resistances of a Sn-0.7 wt. \%Cu lead-free solder alloy. Microelectron. Reliab. 2014, 54, 1392-1400. [CrossRef]

32. Hung, F.Y.; Lui, T.S.; Chen, L.H.; He, N.T. Resonant characteristics of the microelectronic Sn-Cu solder. J. Alloy. Compd. 2008, 457, 171-176. [CrossRef]

33. Wang, F.J.; Xin, M.; Qian, Y.Y. Improvement of microstructure and interface structure of eutectic Sn-0.7Cu solder with small amount of Zn addition. Scr. Mater. 2005, 53, 699-702. [CrossRef]

34. Li, X.A.F.; Zhang, F.; Zu, F.Q.; Lv, X.; Zhao, Z.X.; Yang, D.D. Effect of liquid-liquid structure transition on solidification and wettability of Sn-0.7Cu solder. J. Alloy. Compd. 2010, 505, 472-475. [CrossRef]

35. Alam, M.E.; Gupta, M. Development of extremely ductile lead-free Sn-Al solders for futuristic electronic packaging applications. Electron. Mater. Lett. 2014, 10, 515-524. [CrossRef]

36. Lai, Z.M.; Ye, D. Effect of Al on the microstructure and properties of Sn-0.7Cu solder alloy. J. Mater. Sci. Mater. Electron. 2016, 27, 1177-1183. [CrossRef]

37. Drienovsky, M.; Trnkova, L.R.; Martinkovic, M.; Ozvold, M.; Cernickova, I.; Palcut, M.; Janovec, J. Influence of cerium addition on microstructure and properties of $\mathrm{Sn}-\mathrm{Cu}-(\mathrm{Ag})$ solder alloys. Mater. Sci. Eng. A 2015, 623, 83-91. [CrossRef]

38. Mohran, H.S.; El-Sayed, A.R.; Abd El-Lateef, H.M. Anodic behavior of tin, indium, and tin-indium alloys in oxalic acid solution. J. Solid State Electron. 2009, 13, 1279-1290. [CrossRef]

39. Sharma, A.; Das, S.; Das, K. Electrochemical corrosion behavior of $\mathrm{CeO}_{2}$ nanoparticle reinforced $\mathrm{Sn}-\mathrm{Ag}$ based lead free nanocomposite solders in 3.5 wt.\% NaCl bath. Surf. Coat. Techol. 2015, 261, 235-243. [CrossRef]

40. Zhou, X.; Shen, Y. Beneficial effects of $\mathrm{CeO}_{2}$ addition on microstructure and corrosion behavior of electrodeposited Ni nanocrystalline coatings. Surf. Coat. Techol. 2013, 235, 433-446. [CrossRef]

41. Montemor, M.F.; Simões, A.M.; Ferreira, M.G.S.; Carmezim, M.J. Composition and corrosion resistance of cerium conversion films on the AZ31 magnesium alloy and its relation to the salt anion. Appl. Surf. Sci. 2008, 254, 1806-1814. [CrossRef]

42. Rosero-Navarro, N.C.; Curioni, M.; Castro, Y.; Aparicio, M.; Thompson, G.E.; Durán, A. Glass-like Ce $\mathrm{x}_{\mathrm{y}} \mathrm{O}_{\mathrm{y}}$ sol-gel coatings for corrosion protection of aluminium and magnesium alloys. Surf. Coat. Techol. 2011, 206, 257-264. [CrossRef]

(C) 2019 by the authors. Licensee MDPI, Basel, Switzerland. This article is an open access article distributed under the terms and conditions of the Creative Commons Attribution (CC BY) license (http://creativecommons.org/licenses/by/4.0/). 